\title{
Does Foreign Aid Impact the Development of Private Entrepreneurship in Cameroon?
}

\author{
Vukenkeng Andrew Wujung (Ph.D) \\ Associate Professor of Economics, Higher Institute of Commerce and Management, \\ The University of Bamenda, P.O box 39, Bambili, Cameroon \\ Tafah Bolima \\ Higher Teachers'Training College, The University of Bamenda P.O. Box 39. Bambili, Cameroon
}

\begin{abstract}
s
This paper observes that the effect of foreign aid on private entrepreneurship is controversial. To this end, it assesses the effect of foreign aid on private entrepreneurship development in Cameroon amongst other factors. Data was obtained from the World Bank Development Indicators (WDI) for the period 1980 to 2014.The error correction technique was used to estimate the parameters of private entrepreneurship development in Cameroon. The result showed that there is a positive and significant effect of foreign aid on private entrepreneurship in Cameroon in the long run. In addition, private entrepreneurship was found to increase with increase in real gross domestic product both in the short and long run. Government investment impacted negatively private entrepreneurship in the short and in the long run in Cameroon. From a policy perspective, an important conclusion is that government authorities should improve on the efficiency of foreign aid in order to reduce the lag time this aid takes to exert a significant effect on entrepreneurship development in Cameroon.
\end{abstract}

Key words: Foreign aid, Private entrepreneurship, Error correction model, Cameroon.

DOI: $10.7176 / \mathrm{DCS} / 10-5-06$

Publication date:May $31^{\text {st }} 2020$

\section{Introduction}

The origins of foreign aid as an institutionalized activity dates back to the political and economic ambitions of the United States at the end of World War II. The idea that social and economic 'progress' was not only possible and desirable, but was the one of the main objects of government policy, stretches back at least to the period of Enlightenmentand the great Enlightenment thinker, Adam Smith. The British Colonial Development Act of 1929 provided for monies to be spent on development projects in British colonies (Little and Clifford 1965: 341-2). A more immediate precedent was the 'good neighbour policy' instituted by President Roosevelt in the late 1930s, during which the United States began to provide development loans to Latin American countries through the US Export-Import Bank (Helleiner, 2006).

The provision of aid to developing countries has become an increasingly important part of contemporary international relations. The number of aid donors has increased, and the total amount of aid given to developing countries has risen significantly. For many developing countries, relations with development agencies have become a central part of their international affairs, and for some of the most aid dependent states, foreign assistance has become central to their ability to provide services to their population. For western states, the provision of development aid has become an important instrument for achieving international objectives including the cultivating of political allies, opening markets, fighting terrorism, and constructing regimes of global governance. The provision of foreign aid has also been very controversial. In addition, over the last ten years or so, there has been increasing pressure on western donors to provide aid in a more effective, coordinated and transparent manner. For all of these reasons, foreign aid is an important domain of investigation as concerns practices of global economic governance (Williams, 2017).

Cameroon is classified as a lower-middle-income country. Since it became a unified and independent country in 1961. Cameroon has received significant amounts of foreign aid, most of it from France and the European Economic Community. Since the 1960s, economic growth in the country has been quite significant. Between 1965 and 1980, the gross domestic product grew at an average annual rate of 5.1\%, and at a rate of 2.3\% between 1980 and 1990. To this end, Cameroon seems a good test case for determining the effects of foreign aid on private entrepreneurship and economic growth in developing countries (Mbaku, 2013)

Like other developing countries in Africa, especially other sub-Saharan countries, Cameroon is confronted with many problems that affect their investments, economic growth and development. Even though there is slight improvement in recent years, the country suffers from shortage of capital to finance investments. Structural weakness, climatic change, low level of economic and human development, poorly organized financial institutions and unemployment are other common challenges, which affect investment and economic growth. However, the effect of foreign aid on the private entrepreneurship is controversial. This leads us to questionthe effect of foreign aid on private entrepreneurship development in Cameroon amongst other factors. It is thereforethe objectiveof this 
paper to assess the effect of foreign aid on private entrepreneurship in Cameroon. The rest of the paper is organized as follows:Section two reviews relevant literature in the domain.Section three presents data sources and the method of data analysis. Section four presents and discusses of findings. Chapter five deals conclusion and policy recommendation.

\section{LITERATUREREVIEW}

\subsection{Conceptual literature}

\subsubsection{The Concept of Institutions and Entrepreneurship}

Generally speaking, institutions refer to man-made rules that govern human behaviour (Keizer, 2007). An increasing number of economists agree that "institutions matter" when explaining economic performance. In sociology the concept of 'institution' has always been at the centre of analysis. When comparing the concept as used in different disciplines, we notice that their meaning differs significantly.

To analyse the concept of institutions, science for example aims at a systematic analysis of the universe. When explaining human behaviour, it makes sense to distinguish between human and non-human elements of the universal system. From an existential point of view human life is characterized by uncertainty. Without a reliable interpretation of the situation humans are paralyzed by existential fear. Fortunately, humans are equipped with reason, which is the capacity to frame the situation in particular ways, and to judge situations in terms of opportunities to live a life of their own. Besides reason, the mind harbours bundles of emotions. These emotions are forces that set people in motion. When making a distinction between the mind and the body of a human person, we can interpret the mind as his internal world, while the body can be interpreted as part of his external or empirical world. Humans are able to become aware of the internal world by means of introspection. Sense impressions make us aware of the existence of the external world. Introspection has led to the discovery of series of principal needs that set people in motion to get them satisfied. It also led to the discovery of the capacity to frame the world, not only the empirical, but also the internal world. In this way we achieve meaningful knowledge, which can be interpreted and understood, and used to our own advantage (Keizer, 2007).

Entrepreneurship has traditionally been defined as the process of designing, launching and running a new business, which typically begins as a small business, such as a startup company, offering a product, process or service for sale or hire. The people who create these businesses are called 'entrepreneurs (Yetisen et al, 2015).

According to Schumpeter (1934, 1991; Swedberg, 2000; Fagerberg, 2003), much entrepreneurial activity entails recombination of existing materials and structures, rather than "pure" novelty. Schumpeter regarded this combinatory activity as "the entrepreneurial function." We take a broad view of entrepreneurship, focusing not only on the creation of new business organizations, but also on the generation of new organizational models and policies that change the direction and flow of organizational activity.

A growing number of papers have recently emphasized the diversity of institutional models in developing economies. Djankov et al. (2003: 597) underline that "the interest in institutions revived with the collapse of socialism and the transition of the economies in Eastern Europe, the former Soviet Union, and China to capitalism". The question rapidly became the one of effectiveness of the newly created institutions, and not the one of the speed of their implementation (Murrell, 1995)

\subsubsection{Foreign Aid}

Foreign aid means economic, technical, or military aid given by one nation to another for purposes of relief and rehabilitation, for economic stabilization, or for mutual defense. Some experts hold that aid has enlarged government bureaucracies, perpetuated bad government, enriched the elite in poor countries, or just been wasted. Other argues that although aid has sometimes failed, as they have supported poverty reduction and growth in some countries and prevented worse performance in other. Controversies about aid effectiveness go back decades. Critics such as Friedman (1958), Bauer (1971), and Easterly (2006)have levelled stinging critiques, charging that aid has enlarged government bureaucracies, perpetuated bad governments, enriched the elite in poor countries, or just been wasted. They cite widespread poverty in Africa and South Asia despite three decades of aid, and point to countries that have received substantial aid yet have had disastrous records such as the Democratic Republic of the Congo, Haiti, Papua New Guinea, and Somalia. In their eyes, aid programs should be dramatically reformed, substantially curtailed, or eliminated altogether. Supporters counter that these arguments, while partially correct, are overstated. Sachs \& Snowdon (2005) have argued that although aid has sometimes failed, it has supported poverty reduction and growth in some countries and prevented worse performance in others. They believe that many of the weaknesses of aid have more to do with donors than recipients, and point to a range of successful countries that have received significant aid such as Botswana, Indonesia, Korea, and, more recently, Tanzania and Mozambique, along with successful initiatives such as the Green Revolution, the campaign against river blindness, and the introduction of oral rehydration therapy (Randhawa, 2012). The types of foreign aid include:Disbursements,Bilateral aid, Military aid, Multilateral aid and Humanitarian assistance 


\subsection{Theoretical Literature}

The giving of foreign aid by one country to another is based on aid positivist, aid pessimist and aid conditionality approaches.

This approach focuses on aid positivist theory, which argues that aid is important for poverty reduction and development of developing countries by relaxing saving and foreign exchange problems. According to the "'big bush" theory analysis aid is a catalyst for investment and in turn promotes economic growth and development in capital shortage countries (Sachs \& Snowdon, 2005). It's true that investment in low-income countries suffered by capital shortage and hard currency barriers. Investment is financed by either saving or profit. But the level of saving and profit are very low in most developing countries. Capital inflow in the form of aid helps to enhance investment via providing capital and increasing the availability of hard currency to import investment inputs. So, official aid might have positive influence on the private investment, which limited by these constraints. Hansen and Tarp (2001) supports this argument as foreign aid promotes private investment and economic growth by relaxing saving and hard currency complications of developing countries.

These saving and foreign exchange problems presented in the two gap model which is an extension of HarrodDomar model (Doucouliagos and Paldam 2006 and 2008). Lensink and Bergeijk (1991) also used saving and trade gap model to estimate official finance requirement for low income countries. This model is somehow old but still it is used for MDG calculation (Atisophon et al. 2011). Two gap models show DPI relationship with financial and foreign exchange gaps in the national accounting model;

$\mathrm{Y}=\mathrm{C}+\mathrm{I}+(\mathrm{X}-\mathrm{M})(1)$

Where, income or output is the function of consumption, investment and net export (X-M). Rearranging the equation gives $\mathrm{Y}+\mathrm{M}$ (source of resources used in the economy) equals $\mathrm{C}+\mathrm{I}+\mathrm{X}$ (uses of resource in the economy). The mathematical manipulation of the above equation results in;

$\mathrm{M}-\mathrm{X}=\mathrm{I}-\mathrm{S}(2)$

Equation (2) shows trade and saving gaps of developing countries. The country faces foreign exchange problem when $\mathrm{M}>\mathrm{X}$ and as well investment is lower as there is low level of saving in developing countries. Eliminating of one does not get rid of the other, that is, domestic investment is financed by domestic saving as well as through foreign capital inflow. In this paper the researcher considers foreign capital inflow equals foreign aid and possibly FDI. So from the above equation we get;

$\mathrm{I}=\mathrm{S}+(\mathrm{M}-\mathrm{X})(3)$

Equation (3) is general investment equation. DPI is derived from equation 3

$\mathrm{DPI}=\delta \mathrm{S}+\beta \mathrm{F}(4)$

Where DPI is domestic private investment, $\mathrm{S}$ is domestic saving and $\mathrm{F}$ is foreign saving. $\delta$ and $\beta$ are parameters that measure the rate of domestic and foreign saving, respectively. Equation (4) indicates domestic private investment factored by either domestic saving or foreign saving, i.e., it is caused by endogenous and exogenous factors in the developing countries (J C H Fei et al. 1968). Since domestic saving is very low in low income countries foreign savings (from foreign aid) are capable to finance capital requirements of domestic investment (Lensink and van Bergeijk 1991).

The Pessimist Approachplaces greater emphasis on the effectiveness of aid. The point of discussion begins with why aid is effective in some countries and ineffective in other recipient countries. According to this literature, the difference arises from the behavior of the government in aid recipient countries. By analyzing the ineffectiveness of aid, some economists argue that the inflow of aid to developing countries is discouraging i.e. it damages the economic performance and makes the economy vulnerable to aid dependency. Djankov et al. (2008) hold that aid affects private investment growth in low-income countries through encouraging corruption and weakening institutions. According to them more aid reduces the accountability of the government and encourages corruption and weakens governance systems and institutions. In addition, Herzer and Morrissey (2009) argue that developing countries' governments may engage in corruption and rent seeking activities. If the government is autocrat and undemocratic a high inflow of aid is used for establishing a patronage system and for bribing people to win elections. These proponents hold that foreign aid enlarges social and economic inequality and results in social conflicts in aid recipient countries due to rent seeking activities. This may lead social inequality and cause slow or negative growth of domestic private investment. Also, Herzer and Morrissey (2009) holds that a high inflow of aid causes a resource shift from the productive sector to the unproductive sector. This depresses the export sector of the economy by reducing the profit of the entrepreneurs. Therefore, aid might have negative effect on the investment growth of the aid recipient countries(Snyder, 1996).

Aid Conditionality Approachemphasizes on the conditionality of aid which gives much more emphasis to endogenous source of growth than to foreign financial assistance. According to the aid conditionality literature, foreign capital flow is meaningless without structural changes in recipient countries. Here the basic assumption is that aid can assist the development campaign of developing countries if it is pre-organized by good macroeconomic policies and institutions. The work of Burnside and Dollar (1997, 2000 and 2004) assures the effectiveness of foreign aid depending on the nature of macroeconomic policy of aid in the recipient countries. According to the 
authors aid affects negatively the growth of aid recipient economies unless there are sound policies and institutions. Dollar and Easterly (1999), Burnside and Dollar (1997 and 2004) and Collier and Dollar (2004) argue that aid may not make a difference, what makes a difference is a policy that promotes investment and economic growth. The conditional delivery of aid encourages low income countries to improve on their governance systems and institutions. In developing countries the absence of privatization policy, property right protection, rule of law and others regulations render the entrepreneurial environment unfriendly. The tying of aid to these policies could motivate entrepreneurs and argue that stimulate private investment development. Dollar and Easterly (1999) supports this argument, unless aid is supported by a policy of aid-investment-growth linkage, it does not work especially in Africa. This means that domestic policy and institutional set ups are vital to the investment growth of low-income countries.

\subsection{Empirical literature}

Anumber of studies examined the impact of foreign aid on investment and economic development of developing countries. However, there is no common consensus; generally they found ambiguous results, as such, positive and negative results and also positive effect conditionality on policy and institutional quality. For example, Dollar and Easterly (1999) found out that in the short run, by channeling financial aid to poor countries, investment and economic growth are accelerated. Herzer and Morrissey (2013) found a positive relationship between aid and investment. According to Herzer and Morrissey foreign aid increases the real GDP of African countries by financing domestic investment. Gyimah-Brempong (1992) also found positive and significant effect of aid on the economic growth via affecting national saving and investment.

Burnside and Dollar (1997) conducted a study on aid interaction with macroeconomic policies and concluded that aid without a good policy is a wast of resources. According to them good governance and institutional quality ensuresan effective use of aid and promotes investment and growth via filling development gaps of low income countries. Here the point, it's not the amount of aid received, what matters is policy that improves the economic efficiency of developing countries. However, Hansen and Tarp (2001) found foreign aid to have a positive impact on the growth of private investment without the conditionality of policy environments.

Odada and Mumangeni (2000) used the Jorgenson theory of investment and concluded that real GDP was the only significant determinant of private investment in Namibia. They found that real GDP increases lead to proportionately bigger increases in private investment. Lesotlho (2006) found that in the short-run, private investment in Botswana was determined by public investment, bank credit and real interest rates, while in the longrun, private investment was determined by GDP growth and real exchange rate. In their study, Naudé, Oostendorp and Serumaga-Zake (2000) concluded that investment in South Africa was determined by factors such as the size of the labour cost, certainty of environment and firms' efficiency. Van den Berg (2001) found a positive relationship between capital stock and investment, that is, stock of capital increases as investment increases.

Festus (2009) examined the factors influencing investment in the Namibian economy. With the use of the ordinary least squares (OLS) technique in conjuction with the cointegration and error correction models for the period 1960-2006, found that, in the long run, real investment in Namibia was positively related to and influenced by GDP.

Vukenkeng and Dobdinga (2016) analysed the effect of financial development on private entrepreneurship in Cameroon measured by private capital formation. Using a two stage least square regression technique and found that both elements of financial development (domestic credit and savings mobilization) positively and significantly influence private entrepreneurship in Cameroon. Also, household domestic demand for goods and services had a positive effect on private entrepreneurship.

There is wide store of literature on factors affecting entrepreneurship development around the globe as the literature review above has demonstrated. However, there are limited empirical studies in developing countries such as Cameroon. When these studies exist, very little attention is given to the role of foreign aid in promoting entrepreneurship development. This paper therefore fills this literature gap by investigating the effect of foreign aid on entrepreneurship development in Cameroon.

\section{Methodological Issues}

\subsection{Research Design}

This research work is designed to examine the effect of foreign aid on private entrepreneurship in Cameroon among other things. Therefore, the causal research design was preferred for the study. The causal research design seeks to establish cause-effect relationship among variables which is the case in our work. Based on the objectives of this study, it is clear that it is a multivariate and causal research. It seeks to investigate the relationship between a set of independent variables (foreign aid, government investment, interest rate, credit availability and trade openness) and a dependent variable (private entrepreneurship). 


\subsection{Data Source}

The data used in this study was collected from secondary sources. The data used for this study was thus obtained from the World Bank Data base known as World Development Indicators (WDI). The study covers the period running from 1980 to 2014 making it a 35 years study.

\subsection{Model Specification}

In order to examine the effect of foreign aid on private entrepreneurship in Cameroon, the following model was adopted by modifying the Vukenkeng and Dobdiga (2016) model:

PENT $=\mathrm{f}(\mathrm{FAID}, \mathrm{RGDP}, \mathrm{GINV}, \mathrm{DCPS}, \mathrm{GDS})$.

Where:PENT is private entrepreneurship measured by gross fixed capital formation by the private sector, FAID refers to foreign aid captured by total official development assistance (ODA) and official assistance (OA), RGDP is economic growth measured by real gross domestic product, GINV is government investment, DCPS is domestic credit to the private sector and GDS is gross domestic savings.

The econometric form of the model is given as:

$P E N T=\mu_{0}+\mu_{1} F A I D+\mu_{2} R G D P+\mu_{3} G I N V+\mu_{4} D C P S+\mu_{5} G D S+$

$\varepsilon \mathrm{ENT}=\mu \_0+\mu \_1 \mathrm{FAID}+\mu \_2 \mathrm{RGDP}+\mu \_3 \mathrm{GINV}+\mu \_4 \mathrm{DCPS}+\mu \_5 \mathrm{GDS}+\varepsilon$.

Where $\mu_{0}, \mu_{1}, \mu_{2}, \mu_{3}, \mu_{4}$, and $\mu_{5}$ are respectively the constant term and the coefficient of FAID, RGDP, GINV, DCPS and GDS and $\varepsilon$ is the error term.

A log transformation of all the variables is operated so as to eliminate trends.

$L P E N T=\mu_{0}+\mu_{1} L F A I D+\mu_{2} L R G D P+\mu_{3} G I N V+\mu_{4} L D C P S+\mu_{5} L G D S+\varepsilon$

Where $\mathrm{L}$ refers to the natural $\log$

\subsection{Definition and Measurement of Variables}

A summary description of the variables included in the model is recapitulated in the table below.

Table 1: Definition, measurability and expected signs of variables

\begin{tabular}{|l|l|c|}
\hline \multicolumn{1}{|c|}{ Variables } & \multicolumn{1}{|c|}{ Description } & \multicolumn{1}{|c|}{$\begin{array}{c}\text { Expected } \\
\text { sign }\end{array}$} \\
\hline Private Entrepreneurship (PENT) & $\begin{array}{l}\text { Measured by gross fixed capital formation by the private } \\
\text { sector }\end{array}$ & $/$ \\
\hline Foreign Aid (FAID) & Measured by net official development assistance & Positive \\
\hline Economic Growth (RGDP) & Captured by real gross domestic product & Positive \\
\hline Government Investment (GINV) & $\begin{array}{l}\text { Proxied by gross fixed capital formation by the public } \\
\text { sector }\end{array}$ & Ambiguous \\
\hline Credit Availability (DCPS) & $\begin{array}{l}\text { Proxy for financial development Captured by domestic } \\
\text { credit to the private sector as a percentage of GDP }\end{array}$ & Positive \\
\hline Saving Mobilisation (GDS) & $\begin{array}{l}\text { Measured by gross domestic savings as the second proxy to } \\
\text { financial development }\end{array}$ & Positive \\
\hline
\end{tabular}

Source: the authors

\subsection{Estimation and validation techniques}

\subsubsection{The Error Correction Model (ECM)}

For estimation of the parameters of the model specified, the error correction mechanism was used since the long run relationship between the variables was also of great importance to this study. This method has gained an increased importance in analyses that describe long-run or equilibrium relationship in analysing time series data. This is because time series data are usually not stationary. The estimation procedure begins with testing for stationarity of the variables; the error correction mechanism is only appropriate if all the variables are not stationary at level but achieve stationarity at the same difference levels. The implication of non-stationarity in econometric modelling is grave as it leads to spurious regression. This often manifests when regression of unrelated nonstationary series indicate that the series are correlated (Adam, 1992). Therefore, identification of the time series properties of model variables assists in avoiding the problem of spurious estimates. This is closely followed by testing for causality and co-integration of the variables in the model and then the error correction estimation.

According to Granger's representation theorem (Engel and Granger, 1987), if it is established that variables are cointegrated, it follows that there are forces that tend to restore the equilibrium relationship between variables each time it is broken. However, contrary to the Granger two stages error correction model, the one stage model of Hendry provides the short run elasticities, the error correction term and the long run elasticities at once. We therefore adopt this approach which can be represented as follow using primary difference of variables:

$$
\Delta \mathrm{LPENT}_{t}=\text { Constant }+\beta \Delta \mathrm{LX}_{t}+\lambda \mathrm{LPENT}_{t-1}+\alpha \mathrm{LX}_{t-1}+\varepsilon_{t}
$$

Where $\Delta \mathrm{LX}_{t}$ is the primary difference of the logged values of all the explanatory variables, $\mathrm{LPENT}_{t-1}$ is the error correction term $(\mathrm{ECT}), \mathrm{LX}_{t-1}$ is the lagged value of the log of all the independent variables, $\beta$ is the vector of 
short run elasticities, $\lambda$ is the coefficient of the ECT which measures the speed of adjustment of private entrepreneurship to its long run equilibrium level and must be negative and significantly different from zero and $-\frac{\alpha}{\lambda}$ gives the long run elasticies.

\subsubsection{Unit Root test for stationarity}

Since time-series data are being used, this study should naturally begin by testing for stationarity. This requires the testing of the order of integration of the data set, the unit root tests. The early work on testing for unit root in time series was done by Dickey and Fuller in 1979 (called the DF- test). The basic objective was to test for the null hypothesis. However, the Phillips Perron unit root test will be used in this study. its results are valid even when the requirements of absence of autocorrelation and heteroskedasticity of errors are not met.

Other econometric tests that were done to further validate the results of our study were the Durbin-Watson (DW) and Breush-Godfrey serial correlation LM test for Autocorrelation; the Breusch-Pagan-Godfrey test for heteroskedasticity and the variance inflation factor for multicolinearity and the Jarque-Bera test of normality.

\section{PRESENTATION AND DISCUSSION OF RESULTS}

\subsection{Descriptive Analysis}

The table below shows the descriptive statistics of the variables used in the study, giving the number of observations, the mean, standard deviation as well as the maximum and minimum values.

Table 2: Summary of Descriptive Statisitics of Variables

\begin{tabular}{|l|c|c|c|c|c|c|}
\hline \multicolumn{1}{|c|}{ Variables } & PENT & FAID & RGDP & DCPS & GDS & GINV \\
\hline Mean & $9.91 \mathrm{E}+11$ & $5.50 \mathrm{E}+08$ & $6.93 \mathrm{E}+12$ & 16.02296 & $2.43 \mathrm{E}+09$ & $2.03 \mathrm{E}+11$ \\
\hline Median & $6.35 \mathrm{E}+11$ & $4.97 \mathrm{E}+08$ & $6.50 \mathrm{E}+12$ & 12.52026 & $2.23 \mathrm{E}+09$ & $1.83 \mathrm{E}+11$ \\
\hline Maximum & $2.88 \mathrm{E}+12$ & $1.93 \mathrm{E}+09$ & $1.12 \mathrm{E}+13$ & 31.24235 & $3.63 \mathrm{E}+09$ & $4.47 \mathrm{E}+11$ \\
\hline Minimum & $2.20 \mathrm{E}+11$ & $1.28 \mathrm{E}+08$ & $4.16 \mathrm{E}+12$ & 6.538039 & $1.47 \mathrm{E}+09$ & $6.27 \mathrm{E}+10$ \\
\hline Std. Dev. & $7.23 \mathrm{E}+11$ & $3.78 \mathrm{E}+08$ & $1.74 \mathrm{E}+12$ & 8.415973 & $6.42 \mathrm{E}+08$ & $1.01 \mathrm{E}+11$ \\
\hline Skewness & 0.276305 & -0.010489 & 0.712507 & 0.625303 & 0.293708 & 0.678375 \\
\hline Kurtosis & 1.763646 & 1.061159 & 2.663451 & 1.774974 & 1.737163 & 2.707374 \\
\hline & & & & & & \\
\hline Jarque-Bera & 2.674508 & 0.005456 & 3.126567 & 4.469359 & 2.828895 & 2.809335 \\
\hline Probability & 0.262566 & 0.997276 & 0.209447 & 0.107026 & 0.243060 & 0.245449 \\
\hline & & & & & & \\
\hline Observations & 35 & 35 & 35 & 35 & & 35 \\
\hline
\end{tabular}

Source: The authors from WDI (2016) using Eviews 8

From Table 2 above,private investment has a mean value of $9.91 \mathrm{E}+11$ meanwhile its minimum and maximum values are $2.20 \mathrm{E}+11$ and $2.88 \mathrm{E}+12$ respectively. This indicates to us that private investment has performed poorly over the years under study. This is confirmed by the fact that its means is closer to its minimum value than it is to its maximum value.In a similar light, foreign aid has performed poorly within our period of study. This is ascertained by the fact that its mean value of $5.50 \mathrm{E}+8$ is closer to its minimum value $(1.28 \mathrm{E}+08)$ than it is to its maximum value $(1.93 \mathrm{E}+09)$. In addition to the above situation, the performance of the real gross domestic product variable is seen to be poor over the study period. More so, domestic credit to private sector recorded an all-time low value of 6.538039 during the study period and a maximum value of 31.24235 giving a mean value of 16.02296 indicating a poor performance of the variable during the study period. The table also gives the minimum value of the gross domestic investment variable to be $1.47 \mathrm{E}+09$ and a maximum value of $3.63 \mathrm{E}+09$. Finally, the value of public investment in a similar light has performed poorly within our period of study. This is because it has a mean value of $2.03 \mathrm{E}+11$ which is to a greater extent closer to its minimum value $(6.27 \mathrm{E}+10)$ than its maximum value $(4.47 \mathrm{E}+11)$.

\subsection{Correlation analysis}

Correlation analysis were conducted in order to have a presumption as concerns possible problems of multicolinearity between explanatory variables. 
Table 3: Pair wise correlation matrix table for the variables

\begin{tabular}{c|rrrrrr}
\hline \hline Correlation & PENT & FAID & RGDP & DCPS & GDS & GINV \\
\hline PENT & 1.000000 & & & & & \\
FAID & 0.450627 & 1.000000 & & & & \\
RGDP & 0.960664 & 0.442768 & 1.000000 & & & \\
DCPS & -0.412132 & -0.498888 & -0.328757 & 1.000000 & & \\
GDS & 0.773971 & 0.507049 & 0.777819 & -0.118403 & 1.000000 & 1.000000 \\
GINV & 0.503984 & 0.055136 & 0.685092 & 0.105600 & 0.709507 & 1 \\
\hline \hline
\end{tabular}

\section{Source: The authors from WDI (2016) using Eviews 8}

The correlation analysis of the data presented in table 3 above reveals that all the correlation coefficients at the diagonal are unitary as expected. This shows that there exists a perfect positive correlation between each variable and itself. However, based on the functional relationship specified by our model, it is realised that the relationship between foreign aid and private entrepreneurship is positive. Also, from the control variables, it was realised that the relationship between all the control variables and private entrepreneurship were positive except for domestic credit to the private sector. The correlation between gross domestic saving, economic growth (RGDP) and private entrepreneurship are very strong.All the other correlation coefficients in the table show relationship either positive or negative between the independent variables. However, the correlation coefficient between some independent variables are high showing possibility of multicolinearity existing between the variables. For the purpose of accepting or rejecting the hypothesis of multicolinearity among those variable, a formal test of multicolinearity was conducted.

\subsection{Unit root tests results}

Before estimating the private entrepreneurship function such as specified above, it was important to study the statistical properties of the variables in order to verify whether they are stationary. Table 4 below summarises the results of the ADF tests of each of the variables retained for the study.

Table 4: Augmented Dickey Fuller tests results

\begin{tabular}{|l|c|c|c|c|c|} 
Variable & $\begin{array}{c}\text { test statistics at } \\
\text { level }\end{array}$ & $\begin{array}{c}\text { Critical value at } \\
\mathbf{5 \%}\end{array}$ & $\begin{array}{c}\text { test statistics after first } \\
\text { difference }\end{array}$ & $\begin{array}{c}\text { Critical value at } \\
\mathbf{5 \%}\end{array}$ & Decision \\
\hline LPENT & -0.499775 & -2.951125 & -7.079657 & -2.954021 & $\mathrm{I}(1)$ \\
\hline LFAID & -2.056180 & -2.951125 & -6.031913 & -2.957110 & $\mathrm{I}(1)$ \\
\hline LRGDP & -2.700466 & -3.562882 & -3.954229 & -3.595026 & $\mathrm{I}(1)$ \\
\hline LGINV & -2.565703 & -2.954021 & -2.726086 & -1.952066 & $\mathrm{I}(1)$ \\
\hline LDCPS & -1.485378 & -2.951125 & -4.270912 & -2.954021 & $\mathrm{I}(1)$ \\
\hline LGDS & -1.570771 & -2.951125 & -6.703530 & -2.954021 & $\mathrm{I}(1)$ \\
\hline
\end{tabular}

Source: The authors from WDI (2016) using Eviews 8

The results from the Dicker Fuller stationary test indicate that all the variables were not stationary at level. However, after first difference, all the variables achieve stationarity. The number of time a series is differenced to achieve stationarity determine the order of integration. We therefore conclude that all the variables are integrated of order one or I(1). This justifies the co-integration test and error correction specification mentioned in section 3.

\subsection{Co-integration Analysis}

The co-integration technique makes it possible to test the existence of a relationship of long run equilibrium among non-stationary variables. The summary results of all the five assumptions on the trend of the Johansen (1988) and Johansen and Juselius (1990) procedure are presented below.

Table 5: Johansen co-integration results

\begin{tabular}{cccccc}
\hline \hline Data Trend: & None & None & Linear & Linear & Quadratic \\
\hline Test Type & No Intercept & Intercept & Intercept & Intercept & Intercept \\
& No Trend & No Trend & No Trend & Trend & Trend \\
Trace & 2 & 3 & 3 & 3 & 3 \\
Max-Eig & 2 & 3 & 3 & 2 & 3 \\
\hline \hline
\end{tabular}

\section{Source: The authors from WDI (2016) using Eviews 8}

Results from table 5 reveal that, for almost all the assumptions the trace criterion and the maximum eigen value criterion yield consistent results except under linear trend assumption with intercept where the trace criterion indicate that there are 3 co-integrating equations or vectors as against 2 for the maximum eigen value criterion. What is more important is that the results of the test show that there is at least 2 co-integrating equations in our 
model. Therefore, the Co-integration results indicate that there exists a stable long-run equilibrium relationship between the variables.

\subsection{The regression results: The dynamic model}

In order to examine the dynamic relationships among the variables, an error correction model was specified. The Error Correction Model results using Hendry (1995) specification and procedure are presented in table 6 below:

Table 6: The error correction representation

\begin{tabular}{|c|c|c|c|c|}
\hline \multicolumn{5}{|c|}{ Dependent Variable : D(LPENT) } \\
\hline Variables & Coefficient & Std. Error & t-Statistic & Prob. \\
\hline D(LFAID) & 0.038290 & 0.135860 & 0.281836 & 0.7807 \\
\hline $\mathrm{D}(\mathrm{LRGDP})$ & $2.395375 * * *$ & 0.600408 & 3.989580 & 0.0006 \\
\hline D(LGINV) & $-0.295017^{*}$ & 0.162931 & -1.810691 & 0.0839 \\
\hline $\mathrm{D}(\mathrm{LDCPS})$ & 0.259670 & 0.161130 & 1.611563 & 0.1213 \\
\hline D(LGDS) & -0.116175 & 0.210766 & -0.551204 & 0.5870 \\
\hline ECT & $-0.862054 * * *$ & 0.173118 & -4.979582 & 0.0001 \\
\hline LFAID(-1) & $0.327499 *$ & 0.164306 & 1.993227 & 0.0577 \\
\hline $\operatorname{LRGDP}(-1)$ & $3.252368 * * *$ & 0.718457 & 4.526879 & 0.0002 \\
\hline LGINV(-1) & $-0.433200 * * *$ & 0.122106 & -3.547741 & 0.0018 \\
\hline LDCPS(-1) & $-0.149883 *$ & 0.075914 & -1.974365 & 0.0610 \\
\hline $\operatorname{LGDS}(-1)$ & -0.360361 & 0.247812 & -1.454167 & 0.1600 \\
\hline $\mathrm{C}$ & $-53.10743 * * *$ & 11.94328 & -4.446638 & 0.0002 \\
\hline R-squared & 0.727370 & & & \\
\hline Adjusted R-squared & 0.591055 & Durbin-Wa & & 2.175602 \\
\hline F-statistic & 5.335943 & Prob(F-stat & & 0.000424 \\
\hline
\end{tabular}

Note: $(* * *),(* *)$ and $(*)$ implies significance at 1,5 and 10 respectively

Source: The authors from WDI (2016) using Eviews 8

It is worth noting that the overall model is significant at $1 \%$ given that the probability of Fischer test $(0.000424)$ is less than 0.01 . Also, it is observed that $59.11 \%$ of the variation in private entrepreneurship in Cameroon is jointly explained by variation in all the independent variables of the model.

The short run elasticities are provided by the coefficients of the logged values of variables at first difference. Results from table 6 above reveal that the coefficient of foreign aid is positive (0.038290) which implies that there is a positive effect of foreign aid on private entrepreneurship in the short run as expected. A unit percentage increase in foreign aid will bring about $0.04 \%$ increase in private entrepreneurship in Cameroon. However, the finding was found to be statistically insignificant.This short run result is contrary to that of Dollar and Easterly (1999) but in line with that of Snyder (1996) and Burnside and Dollar (1997). Furthermore, results above show that economic growth has a positive effect on private entrepreneurship as the coefficient of LRGDP is positive (2.395375). More precisely, a one percent increase in national output will result in a $2.39 \%$ increase on private entrepreneurship depicting a multiplier effect of economic growth on private entrepreneurial activities. This result is in line with our prior expectation. In addition, the result is significant at $1 \%$ level.

In addition, we observe that government investment has a negative effect on private entrepreneurship in the short-run as denoted by its negative value of -0.295017 . The implication is that a unit change in the level of government investment in Cameroon will lead to a $0.295 \%$ reduction in the level of private entrepreneurship. This result falls in line with our expectation as we noted the ambiguity of the effect of government investment on private entrepreneurship. This result was seen to be significant at a $10 \%$. The short-run elasticity value of LDCPS $(0.259670)$ indicates a positive effect of credit availability on private entrepreneurship. This result affirms our a priori expectation. However, this result is statistically insignificant as its $\mathrm{P}$ value $(0.1213)$ exceeds the $10 \%$ level of significance. Also gross domestic saving has a negative relationship with private entrepreneurship in the shortrun. This result contradicts our a priori expectation. However, it is also seen to be insignificant even at a $10 \%$ level. Testing the long term causality is done by considering the significance of the coefficient of the error correction term (ECT) in the error correction model. ECT in this model is negative as required by the stability condition of the dynamic model and significant at $1 \%$ level. The value -0.8620 of the coefficient of the error correction term means that $86.2 \%$ of the disequilibrium in private entrepreneurship observed at period $t-1$ was eliminated. This result indicates that the speed (rate) at which private entrepreneurship adjusts itself to its long term level in the Cameroonian economy following shocks is relatively fast. The long run elasticities are presented in table 4.7 below. 
Table 7: long run elasticities of private entrepreneurship in Cameroon

\begin{tabular}{lccc}
\hline \multicolumn{1}{c}{ Variables } & Coefficients & ECT & L.R elasticities \\
\hline LFAID & $0.327499^{*}$ & -0.862054 & $0.379905^{*}$ \\
LRGDP & $3.252368^{* * *}$ & -0.862054 & $3.772812^{* * *}$ \\
LGINV & $-0.433200^{* * *}$ & -0.862054 & $-0.502521^{* * *}$ \\
LDCPS & $-0.149883^{*}$ & -0.862054 & $-0.173867 *$ \\
LGDS & -0.360361 & -0.862054 & -0.418026 \\
\hline
\end{tabular}

Source: Authors

Table 7 above gives the long run elasticity of the explanatory variables used in the study. It indicates that in the long run, foreign aid and economic growth has a positive effect on private entrepreneurship as denoted by their positive elasticity coefficient above. This implies an increase in this variable will lead to an increase in private entrepreneurship.This finding falls in line with those of Herzer and Morrissey (2013), Gyimah-Brempong (1992) and Herzer and Grimm (2012) and contrary to that of Munemo (2011). This results confirm that of Lesotlho (2006), Festus (2009) and Odada and Mumangeni (2000). The table also identifies that government investment, domestic credit to the private sector and gross domestic saving have a negative relationship with private entrepreneurship.We observed a negative effect of domestic credit to the private sector on private entrepreneurship in the long run which corroborates the finding of Greene and Villanueva (1991) but contradict the findings of Vukenkeng and Dobdinga (2016). Finally, gross domestic savings had no statistical effect on private entrepreneurship in the Cameroonian context both in the short and long run. This contradicts the prominent neoclassical growth models and the Harrod Domar model which regards savings as a main source of investment.

The long run elasticity values an increase in these variables will lead to a decrease in private entrepreneurship in Cameroon. This finding contradicts that of Lesotho (2006), Abdul, Davide and Petia (2015) and in line to that of Thanapat Reungsri (2010).

Further validity tests results indicate that there was no problem of serial correlation of errors as the Breusch Godfrey probability is greater than $5 \%$. The errors are both normally distributed and homoscedastic as the P-values of Breusch Pagan and Jarque Bera are all greater than 5\%. Since the hypothesis of heteroscedasticity is rejected, we therefore conclude that the variance of residuals are constant across time. In addition, the VIF of the variables suggest that multicolinearity is not a major concern in the model as the VIF of the variables are less than 10.

\section{CONCLUSION AND POLICY IMPLICATION}

This study paper set out to analyse the effect of foreign aid on private entrepreneurship amongst other variables in Cameroon. The results of the study revealed that there is positive and significant effect of foreign aid on private entrepreneurship in Cameroon in the long run. In addition, private entrepreneurship was found to increase with increase in real gross domestic product both in the short and long run. On the contrary, government investment impacted negatively private entrepreneurship in the short and in the long run which implies that public investment crowds out private entrepreneurship in Cameroon.

From the foregoing findings, this study justify the need for government authorities to improve on the efficiency of foreign aid in order to reduce the lag time this aid takes to exert a significant effect on entrepreneurship development in Cameroon. This can be achieved by reducing the bureaucracy surrounding the management of foreign aid in Cameroon. Furthermore, measures or policies aimed at stimulating economic growth should be reinforced as these measures will definitely have a multiplier effect on private entrepreneurship in the country. Such policies may include strengthening a good business climate.

An efficient allocation of resources between the public sector and the private sector should be guaranteed by the government. Public investment should be directed towards constructing and maintaining public amenities such as road networks, communication facilities which will contribute in reducing the cost of carrying out business in Cameroon.

\section{References}

Abdul A., Davide F. and Petia T. (2015), "The Macroeconomic Effects of Public Investment: Evidence from Advanced Economies". IMF Working Paper, May 2015.

Atisophon, V., Bueren, J., De Paepe, G., Garroway, C., \& Stijns, J. P. (2011). Revisiting MDG cost estimates from a domestic resource mobilisation perspective.

Bauer, P. T. (1971). Economic history as theory.Economica, 38, 163-179.

Blejer, Mario, and Mohsin Khan. 1984. Government policy and private investment in developing countries. IMF Staff Papers 31:379-403.

Burnside, A. C., \& Dollar, D. (2000). Aid, policies and growth. American Economic Review, 90(4), 847-868.

Burnside, A. C., \& Dollar, D. (2004). Aid, policies and growth. Revisting the evidence World Bank Policy Research Working No 3251.

Burnside, C. and Dollar, D. (1997), Aid, Policies, and Growth, Policy Research Working Paper 1777 [online] 
Washington, D.C.: World Bank. http://www.worldbank.org.

Collier, P., \& Dollar, D. (2002). Aid allocation and poverty reduction. European Economic Review, 45(8), 14751500 .

Collier, P., \& Dollar, D. (2004). Development effectiveness: what have we learnt economic journal, 114, F244F271.

Cooper, A. C., \& Schindler (2006). Determinants of satisfaction for entrepreneurs. Journal of Business Venturing, $10(6), 439-457$.

Djankov, S., Glaeser, E., La Porta, R., Lopez-de-Silanes, F., \& Shleifer, A. (2003). The new comparative economics. Journal of comparative economics, 31(4), 595-619.

Djankov, S., J.G. Montalvo, and M. Reynal-Querol (2008) the course of Aid. Journal of economic growth, 13, 169-194

Dollar, D. and W. Easterly (1999) The search for the key: aid, investment and policies in Africa. Journal of African economies, 8, 546-577

Doucouliagos, H., \& Paldam, M. (2008). Aid effectiveness on growth: A meta study. European Journal of Political Economy, 24(1), 1-24.

Doucouliagos, H., \& Paldam, M. (2009). The aid effectiveness literature: The sad results of 40 years of research. Journal of Economic Surveys, 23(3), 433-461.

Easterly, W. (2006). Planners versus searchers in foreign aid.Asian Development Review, 23(1), 1-35.

Fei, J. C., \& Ranis, G. (1968). Foreign assistance and economic development: comment. The American Economic Review, 58(4), 897-912.

Fei, J.C.H. and G. Ranis, 1968 Economic Development in Historical Perspective. The American Economic Review, 1969. 59(2): p. 386-400.

Festus N. N (2009), "Factors Influencing Investment: The Case of the Namibian Economy". MSc. Thesis submitted to the University of Namibia.

Friedman, M. (1958). Foreign economic aid: Means and objectives. In G. Ranis (Ed.),The United Statesand the development economies(pp. 250-263). New York: Norton.

Greene, Joshua, and Delano Villanueva. (1991). Private investment in developing countries: An empirical analysis IMF Staff Paper 38 (1): 33-58.

Guncavdi, Oner, Michael Bleaney, and Andrew McKay. 1998. Financial liberalization and private investment: Evidence from Turkey. Journal of Development Economics 57:443-55.

Hansen, H., \& Tarp, F. (2001). Aid and growth regressions. Journal of Development Economics, 64(2), 547-570.

Helleiner, G.K., (2006) Manufactured Exports from Less-Developed Countries and Multinational Firms. The Economic Journal, 1973. 83(329): p. 21-47.

Herzer, D. and Morrissey (2009) The long-run effect of aid on domestic ouput. CREDIT Research paper 09, 01. Center for Research in Economic Development and International Trade. Nottingham.

Herzer, D., \& Morrissey, O. (2013). Foreign aid and domestic output in the long run. Review of World Economics, 149(4), 723-748.

Keizer, W. P. (2007). Fast low-sidelobe synthesis for large planar array antennas utilizing successive fast Fourier transforms of the array factor. IEEE Transactions on Antennas and Propagation, 55(3), 715-722.

Lensink, R. \& P. A. Van Bergeijk (1991) 'Official Finance Requirements in the 1990s', World Development 19(5): 497-510.

Lesotlho, P. (2006). An investigation of the determinants of private investment: A case of Botswana. A mini-thesis for a Master in Economics. Cape Town: University of Western Cape.

Little, I. M. D., \& Clifford, J. M. (1965). International aid. A discussion of the flow of public resources from rich to poor countries with particular reference to British policy. International aid. A discussion of the flow of public resources from rich to poor countries with particular reference to British policy.

Mbaku, J. M. (2013). Building Opportunities: Addressing Africa's Lack of Infrastructure.

Naudé, W., Oostendorp, R. and Serumaga-Zake P. (2000). Determinants ofinvestment and exports of the South African manufacturing firms: Firm-levelsurvey results. A conference paper. St. Catherine's College, Oxford University.

Odada, J.E. \& Mumangeni, J. (2000). Demand for investment in Namibia: Anempirical analysis. Windhoek: University of Namibia, Multi-Disciplinary Research and Consultancy Centre.

Ramirez, Miguel D. 1994. Public and private investment in Mexico, 1950-90: An empirical analysis. Southern Economic Journal 61 (1): 1-17.

Randhawa, G. K. (2012). Foreign aid in economic development. International Journal of Computing \& Business Research, 1-10.

Sachs, J. D., \& Snowdon, B. (2005). A Global Compact to End Poverty: Jeffrey Sachs on stabilisation, transition and weapons of mass salvation.

Sachs, Jeffrey. 2005. The End of Poverty: Economic Possibilities for Our Time. New York: Penguin Press. 
Schumpeter, J. A. (1934). The theory of economic development. Cambridge, MA: Harvard University Press.

Snyder, D.W. (1996) Foreign aid and private investment in developing economies. Journal of International Development, 8, 735-745

Thanapat R. (2010), “The Impact of Public InfrastructureInvestment on Economic Growth inThailand". PhD Thesis.

Van den Berg, H. (2001). Economic growth and development. New York: McGrawHill Irwin.

Vukenkeng A. W. and Dobdinga C. F. (2016) The Role of Financial Development on Private Entrepreneurship in Cameroon. A journal of economics and sustainable development Vol 7,No21 pp118-124.

Williams, C. C. (2007). Entrepreneurs operating in the informal economy: necessity or opportunity driven? Journal of Small Business \& Entrepreneurship, 20(3), 309-319.

Yetisen, A. K., Montelongo, Y., Qasim, M. M., Butt, H., Wilkinson, T. D., Monteiro, M. J., \& Yun, S. H. (2015). Photonic nanosensor for colorimetric detection of metal ions. Analytical chemistry, 87(10), 5101-5108. 